\title{
COMO VER O MUNDO: A VANGUARDA ROMÂNTICA DE FRANZ MARC
}

\author{
Lennon Noleto ${ }^{1}$
}

RESUMO: Este ensaio trata do pintor Franz Marc. Por meio da produção do artista, prentendemos explorar a relação ainda existente entre a estética romântica e expressionismo.

PALAVRAS-CHAVE: Franz Marc; Expressionismo; Romantismo; Pintura.

\begin{abstract}
This essay aims to analyse some Franz Marc's artworks. It's argued that many aspects in German Expressionism were still related to the romantic aesthetics. This writing intents to explore this tie throught Marc's paintings.
\end{abstract}

KEYWORDS: Franz Marc; Expressionism; Romanticism; Painting. 

"Pois a transição do corpo para a alma, de acordo com vossa própria representação, não pode dar-se de forma contínua, mas apenas através de um salto, que vós, todavia, afirmais querer evitar."

Schelling, Ideias para para uma filosofia da natureza, Introdução.

\section{1.}

Os Filhos do Barro é um conhecido ensaio de Octávio Paz no qual o autor se debruça sobre as relações entre a arte de vanguarda e o que seria o projeto estético romântico. Esta relação - e por que não dizer um "eco" ou um "imaginário"? - parece recair, como de costume, sobre a tópica da radicalização do eu enquanto subjetividade contra o mundo, o que, no século $\mathrm{XX}$, culmina no posicionamento "belicoso" que se vale da superação da figuração e do drama de si mesmo. Contudo, haveria mais em jogo. Segundo o autor mexicano, é-nos aberto o campo da mágica conversão do mundo em prosa, segundo a qual, desde Hölderlin, o poético é o verbo que tudo constrói e que estabelece entre os homens a comunidade enquanto elo metafísico. Paz exemplifica que, ao escrever Hyperion, Hölderlin não trata somente da luta por uma ordem social mais justa, mas também da prentesão de uma comunidade cujo selamento é o poético. Neste sentido, o poeta é senão aquele que estabelece o kósmos; já a atividade poética, o que une o terreno ao divino:

A palavra poética é mediação entre o sagrado e os homens e, assim, é o verdadeiro fundamento da comunidade. Poesia e história, linguagem e sociedade, a poesia 
como ponto de intersecção entre o poder divino e a liberdade humana, o poeta como o guardião das palavras que nos preserva do caos original (PAZ, 1984, p. 62)

É como se pudéssemos apontar em Hölderlin uma transgressão à politéia platônica: o artista, que fora o imitador do terreno da aparência, o criador de fantasmas (tồ eídōlou poiētē) que não precisa entender o funcionamento dos objetos e "julga na alma à margem da medida" ${ }^{2}$ é então o rei, aquele que tem consigo o poder de instituir a ordem, comunicar-se com o sagrado, que é somente o próprio caos. Tal aspiração a essa comunidade justa cujo selamento é a poesia - e por que não dizer "o poético"? não será, entretanto, buscada pela via sacra e ascética. O poeta não somente media, mas une a finitude a infinitude, torna profano o sagrado, sacraliza a materialidade. Nesta tentativa há um caráter violento, no qual o sentimento aparece como fator de transgressão. Numa comunidade almejada como a de Hyperion, a poesia seria, sobretudo, cultuada, estabelecendo assim o erótico, o destrutivo, o contraditório que une o que é costumeiro ao desconhecido:

o gosto pelo sacrilégio, o amor pelo estranho e pelo grostesco, a aliança entre o cotidiano e o sobrenatural. Em uma palavra, a ironia - a grande invenção romântica. Precisamente a ironia - no sentido de Schlegel: amor pela contradição que cada um de nós é e consciência dessa contradição - define admiravelmente o paradoxo do romantismo alemão. (Ibdem, p. 63)

Esta possibilidade da união entre os dois terrenos abre as portas da arte justamente ao diabólico - "o que contesta", o divergente - sem que, contudo, isto se resuma à preceptiva 
da dor da contradição. Para além disso, seguindo as intuições de Paz, a negatividade que aqui se instaura parece emergir como reflexão a partir do sujeito, ou melhor, como sua própria vontade de estabelecer uma polaridade. Diga-se de passagem, não é por acaso que Hegel, ao tratar da dissolução da forma romântica da $\operatorname{arte}^{3}$ em sua Estética, aponta para o primado da subjetividade nas expressões artísticas oitocentistas, sobretudo na pintura e na poesia. A arte dedica-se à prosa descritiva do mundo, conectando os motivos mais costumeiros aos motivos mais elevados. A expressões artísticas dão a ver, por um lado, uma valorização do caráter particular do mundo prosaico e, por outro, uma interioridade que se torna cada vez mais exterior, de modo que a forma e o conteúdo, nessa extrema particularidade, captem toda a contingência existente. No momento da exposição, a obra já é a própria contingência. (HEGEL, 2000, 329).

Ora, não é essa devoção pelo prosaico que flagramos na saga de Werther? Goethe fá-lo dizer em carta de 4 de maio a seu amigo Wilhelm: "A própria vila é desagradável, mas, ao redor, há uma inefável beleza natural. Foi o que decidiu o Conde von M. ao construir seu jardim.(...) Já na entrada, sente-se que não foi um jardineiro industrioso que o desenhou, mas um coração sensível que queria aqui se conhecer" (GOETHE, 1920, p. 9). $\mathrm{Na}$ carta subsequente, de 10 de maio, Werther se mostra de tal modo envolto nesta atmosfera que, metaforicamente, passa de um poeta a um pintor, sem qualquer instrução técnica aparente, mas como se fosse meramente guiado: "Sou tão feliz, meu caro, tão mergulhado no feliz sentimento desta existência, que minha arte [a poesia] sob isso padece. Não poderia desenhar agora sequer um traço e nunca fui um pintor tão grandioso 
quanto neste momento" (Ibdem, p.10). Ao longo da narrativa do sofrimento em função do envolvimento com Charlotte, o jovem, na antipenúltima de suas cartas, encontra-se em total desortem com seus sentimentos, movido por desejos bruscos e destrutivos; isto ocorre paralalemente ao degelo do rio próximo à sua casa, degelo este que, com toda sua força, arrasou as proximidades e, como um mar furioso, destruiu um recanto no qual Werther se encontrara com sua amada. Em dado momento, no defrontar-se com o fenômeno natural, a personagem deseja unir-se a este (se necessário, lançando-se às águas) transpondo seus limites como humano, tornando-se uma força tão grande quanto os sentimentos que enclodem dentro de si. (Ibdem, p. 167). Na medida em que seguiu a via da sinuosidade, o romantismo aflingiu a divindade, construindo assim o ornamento a partir da angústia da contradição; e esta vida de paradoxo parece dar ensejo à crença que a partir daí se constrói: uma não-religiosidade religiosa. A morte de deus, conclui Paz, é portanto uma tópica romântica (PAZ, pp. 68-69).

Seja a introspecção que orna o jardim, a genialidade dada à arte ou a confluência violenta dos sentimentos, desempenha-se uma relação que, mesmo na internalidade da narrativa, não pode ser prontamente atribuída à intimidade com a natureza, mas, antes de tudo, à uma consciente subjetivação da objetividade, o que leva a crer que tempo e espaço fazem sentimento e fenômeno natural coincidirem. É, pois, esta primazia da individualidade que caracteriza a época moderna - a beleza não é meramente ideal, mas é suplantada pelo interesse. Neste sentido, conforme nos informa Peter Szondi, já é sabido por Friedrich Schlegel que os tempos modernos tornam o entendimento capaz de estruturar relações, separar e unir de modo arbitrário, caracterizando assim não meramente uma "época de cisão", mas que também pode cindir: 
$\mathrm{Na}$ época moderna, “o poder que põe em movimento e que assegura a execução repousa sem dúvida na vontade, mas é o entendimento que é o poder legislador que dirige, por assim dizer, um princípio diretor supremo que conduz e guia a força cega, decide sua orientação, determina a ordem da massa total, e separa ou reune as partes diferentes arbitrariamente". A emancipação do entendimento é a origem dos tempos modernos; sua ação consiste em separar e misturar. É por isso que Schelegel chama esta idade "química". Todas as relações são destruídas, colocadas em questão ou subsumidas à reflexão. Se a essência da antiguidade é a coesão, a da época moderna é a divisão. (SZONDI, idem, p. 97)

Nesta idade "química", a modificação não implica somente a manipulação da forma, mas, de modo mais radical, a modificação da estrutura e a possibilidade de conhecer e ao mesmo tempo criar. Esta sedimentação pretensamente natural não é mera característica geral do que chamamos condensadamente "modernidade", mas é tão somente romântica porque é sabida e paralelamente epistêmica e demiúrgica, é ciência e poesia. Isto, como depreendemos de Márcio Suzuki, não dista muito do que o próprio termo romantismo carrega: escrever em romanice (línguas provindas de latim vulgar), propagar um imaginário que se tinha da cultura romana; e, conforme estava em voga na Jena do século XIX, "a própria busca de novas formas de expressão literária e filosófica." ${ }^{4}$ Extremo ato de "dar a ver", a poética romântica impossibilita, de uma vez por todas, o real como em si e, transfigura a forma, torna-a inabarcável, verborrágica. Em suma, encontrase num sublime tal como diagnosticado por Hegel naquele 
século: desorientação desta subjetividade, acomentimento do real pelo ilusório na sociedade burguesa ${ }^{5}$. A passagem entre séculos dramatizou este desenvolvimento tão logo o mundo fora desencantado e a racionalidade materializada nos processos de modernização. Neste cerceamento, para dizermos de modo mais adequado ao século XX, o eu deseja projetar-se a todo custo. Subjetividade que se expande ao ponto de se dissolver: o diálogo do todo consigo mesmo da arte de vanguarda já fora profetizado pelos românticos.

A tentativa de apreender o Romantismo enquanto problema subjacente ao fenômeno das vanguardas artísticas encontra, logo de início, um problema de delimitação. Conforme apontamos de início, encontramos muito menos algum tipo de "influência" do que um imaginário comum que, certamente, não era intencionalmente romântico. Neste sentido, associar o momento histórico das vanguardas ao Romantismo (igualmente histórico) requer, de antemão, a perícia de conceber este como um registrito poético/poiético que circulara nas produções artísticas, evitando assim o condensamento de uma categoria estética. Expomos, a seguir, de que modo as pretensões de Franz Marc (e, de certa forma, dos demais artistas do Cavaleiro Azul) dialogam com a questão.

O historiador e crítico de arte Erwin Panofsky relata que, em 1919, o Madril de Franz Marc torna-se um paradigma no Salão de Arte de Hamburgo. A tela recusava qualquer intepretação figurativa, sendo irreconhecível ao público a figura do animal pressuposto pelo título da obra. Diante de si, os frequentadores, ainda pouco habituados aos princípios expressionistas, viam curvas 
as quais infatizavam muito menos sua geometria que suas relações cromáticas. (PANOFSKY apud LICHTENSTEIN, pp. 91-92). Um olhar sobre os escritos de Marc nos conduzem a um lugar comum da crítica: representar o mundo a partir da visão das criaturas que habitam seu espaço pictórico; trata-se, em suma, de ver o mundo como os animais, os quais ainda possuem a pureza que o ser humano já perdera no mundo em que mesmo as "batitidinhas" foram modernizadas conforme afirma Marc em um de seus escritos.

Desde a União dos Novos Artistas de Munique, encontramos na arte alemã a defesa à abstração como um subterfúgil espiritual - termo este que pode ser inapropriado, uma vez que, para aqueles artistas, a espiritualidade era como uma origem perdida e menos uma utopia a ser alcançada. Esta união é considerada um antecedente do Cavaleiro Azul, desde a qual o plano espiritual foi uma questão. Em um primeiro momento, deve-se isto a Wassily Kandinsky, que insiste na relação com o misticismo, com a religiosidade da iconografia russa, o que era ao artista um acesso ao enigma por trás da materialidade. Diga-se de passagem, o pintor russo sanaliza em suas Composições uma adesão à crença de seu tempo: Kandinsky, tal como a ciência que lhe era contemporânea, dedica sua atenção ao invisível, à pura vibração, às partículas que são a "causa misteriosa" do real (CARDINAL, 1988, p.77) A busca por correspondência a este estímulo - talvez esse seja um termo adequado - requer uma arte que faça essa passagem ao invisível, distanciando-se assim de uma figuração puramente simbólica ${ }^{6}$, concebendo natureza enquanto gesto, em suma, a abstração enquanto linguagem adequada. (Idem, Ibdem).

No prefácio à segunda edição do Almanaque do Cavaleiro $A z u l^{7}$, Franz Marc inicia suas considerações partindo de uma frase do poeta Theodor Däubler: "Tudo que vem a ser, pode ser iniciado somente na Terra." ${ }^{8}$ Aquele grupo de artistas dá a esta primeira publicação (e do qual não se foi além) um sentido 
que, segundo o pintor, pulsa misteriosamente numa nascente com mil pontos, que se vela e se desvela, que canta e susurra. (KANDINSKY; MARC, 1914, prefácio). Não se trata unicamente de fazer emergir o espiritual, mas uma busca por uma "pureza" que ainda resta, alguma possível esfera ainda não administrada pela modernidade:

Com radiestesia, adentramos a arte daquele tempo e do presente. Nós somente mostramos o vívido, o que é intocado pela coerção da convenção. $\mathrm{Na}$ arte, tudo que nasce de si mesmo, vive de si mesmo, e não anda com as muletas do hábito, e que mereceu nosso dedicado amor. Onde vimos uma rachadura, lá insistimos; somente por ali, por baixo dali esperávamos uma força que um dia viria à luz. (Ibidem)

Dois anos após a formação do grupo, embora não tenha chegado ainda o tempo do ver e do ouvir, para nos valermos das palavras de Kandinsky, os artistas têm como aposta a captação das energias do universo, não pela força da organicidade, mas a própria força. Por este motivo, Marc nos fala de radiestesia: a pretensa sensibilidade para as energias cósmicas que formam o universo. A crença neste princípio criador que atravessa todas as coisas, que no Cavaleiro Azul pode podemos facilmente confundir com uma crença religiosa, é para Franz Marc, até o fim da vida, seu caminho. Procuremos avaliar isto.

Acerca da figuração animal, o pintor se corresponde com o editor e historiador Piper em 1910: para Marc, não se trata de instaurar uma orientação da pintura de animais. Sua busca, nas palavras do próprio, é por um "estilo bom, puro e limpo" e, por meio deste panteísmo, sentir "o tremor e o fluir do sangue na natureza, nas árvores, nos animais, no ar" (MARC, 1978, p. 98). 
Esta figuração animal (Tierbild) é entendida pelo artista como uma oposição a artistas como Signac e van Gogh, que teriam praticado uma animalização (Animalisierung), por meio da qual não somente aquilo que pintava, mas o próprio quadro, se tornariam animalizados. Ao operar essa oposição, Marc declara sua pretensão:

A circulação do sangue nos corpos de ambos os cavalos, expressados pelos paralelismos diversos e as vibrações das linhas. $\mathrm{O}$ observador não há de perguntar pela raça do cavalo, mas externar a vida animal interior e tremente. (Ibdem)

Esta força, embora sempre presente, não será perenemente violento, mas acompanhará a manifestação da "vida" e configurar-se-á de acordo com o páthos que cada figura parece comportar. Para melhor enxergarmos tais direcionamentos, observemos duas telas de 1911 entre as quais uma oposição pode se construir. Cavalo Azul I (figura 1) apresenta em primeiro plano um equino azul cuja cabeça e pescoço se inclinam. Embora suas patas sugiram que ele esteja de pé em pleno solo, o animal aparenta estar imerso em tamanha introspecção que chega a se deslocar do fundo, aliado não somente à iluminação que lhe fornece uma sacralidade, mas também à discrepância entre a solidez sutilmente geométrica de seu corpo e a simplicidade (em certo ponto, riscos) do plano que o acompanha. Esta simplicidade é mais evidente na parte inferior da tela, onde vermelho e verde se encontram como profusões criando contraste de caráter um tanto superficial; esta relação, porém, parece se resolver na medida em que estas duas cores jogam num sentido tangente ao corpo do cavalo. Atrás do animal, algo revelador: um fundo 
amarelo que "surge" entre as formações rochosas, cercado à direita por matizes de roxo e lilás que o complementam.

Ao compararmos aquela tela ao Cão deitado na neve (figura 2), notamos uma inversão do valor do amarelo. Nesse quadro, as cores não são aplicadas de modo tão puro quanto em Cavalo Azul I. A neve, sobre a qual o cão deita, parece cercá-lo propositalmente seguindo as dobras do seu corpo com porções azuladas. O cão, orgânico em sua expressão e, ao mesmo tempo, lógico em sua constituição, repousa em traços expressivos, em amarelo e branco aplicados sem muito tratamento em alguns pontos. O animal é acompanhado por um sobreamento lilás.

A relação centralizada nos quadros - o azul e o amarelo - é, no mínimo, uma aplicação das teorias de Franz Marc, discorridas em suas cartas com August Marcke em 1910, segundo nos conta a historiadora da arte Shulamith Behr. Nestas teorias há uma divisão sexual que significa o uso das cores:

Como expresso em suas cartas para Marcke em 1910, Marc formara teorias complexas que conferiam atributos psicológicos e sexuais às cores primárias e secundárias; por exemplo, o azul estava associado ao princípio espiritual, masculino e o amarelo ao princípio terreno, próprio das qualidade femininas. (BEHR, 2000, p. 44)

Como prossegue Behr, mesmo com seu espírito marcadamente crítico ao instituicionalismo da época em diversos sentidos, os artistas muitas vezes não estavam salvos de concepções patriarcais em voga. Em todo caso, a partir dessa sistematização compartilhada por Marc e outros artistas, a divisão é importante para entendermos a atuação da força mística do azul, espiritualidade e, ao mesmo tempo, o guia à mesma. Se observamos no Cavalo Azul I a 
sacralidade do princípio masculino e modelador trazido ao primeiro plano em toda sua pureza digna de devoção, o Cão deitado na neve parece figurar um "retorno" por meio do corpo que, imerso nesse princípio feminino receptivo, alonga-se em movimento centrípeto fechando-se ao diálogo. Deve-se levar em consideração que esta oposição, em especial, insiste em determinar o que guia e que deve ser guiado, o que é intelecto e o que é matéria. Esta concepção parece se intensificar, por exemplo, no trabalho Vaca Amarela: grosso modo, trata-se de um animal doméstico que simplesmente atravessa de modo tranquilo uma paisagem agressiva que, no entanto, parece se relacionar com seu movimento. A porção azul que a vaca carrega foi aplicada com intenção visivelmente simbólica, de modo que o amarelo se mostra como fator determinante para sua disposição. A idealidade do feminino é aqui explicitada.

Por mais que sejamos levados à conclusão de que as figuras de Franz Marc encerram-se ou correm em direção à espiritualidade, devemos levar em consideração o panteísmo o qual o artista buscou até o fim de sua vida. Não parece ser uma pretensão do pintor explicitar a cisão categórica e sobrepor a espiritualidade à natureza, mas resolver esta oposição, chegar finalmente à união, ao seu destino. Neste sentido, Marc estaria ligado fortemente a uma compreensão romântica. Mas de que modo?

A bem da verdade, se pensarmos na recepção por parte dos artistas, trata-se mais precisamente de um amálgama "romantismo/simbolismo". Amálgama este que já se faz presente no fin-de-siècle: fora fundada pelos simbolistas de Paris a Revue Wagneriènne, que se dedicava ao principalmente ao estudo e à crítica do compositor alemão Richard Wagner. Registros deste tipo, que apontam já no século XIX o investimento na revelação mística no que se tinha por "romantismo". Em Munique esta compreensão ecoa e, mais radicalmente, constitui a postura 
crítica dos artistas em relação à modernidade. Tendo em vista os seus limites que mundo exterior atinge, resta, em certo sentido, uma saída internalista. Sobre isto, afirma Shulamith Behr:

(...) os escritos de Kandinsky, Werefkin e Marc eram mais teóricos e investidos de um maior senso místico. Imbuídos das heranças do romantismos e do simbolismo, questionavam a representação impressionista do mundo exteior, subtituindo-a por uma arte gerada pela "necessidade interna”. (...)

Se considerarmos, por exemplo, que a pintura impressionista aposta no olhar, na pesquisa da cor, a obsvervação do exterior, no Moulin de la Gallete, enfim, adentra a modernidade, a resistência expressionista pode ser vista, em via contrária, como busca pela sacralidade, ou ainda, de acordo com Franz Marc, numa esperança de que a modernidade pare de industrializar as ideias da floresta primitiva (KANDISNKY; MARC, prefácio). Mas resistência, para arte de vanguarda alemã, é agir violentamente: submeter a linguagem aos extremos que variam da hibérpole à simplicidade agressiva, negar os valores da sociedade burguesa, a lógica e a causalidade, mergulhar na obscuridade, nas distorções do perspectivismo. Assim se referiu Marion Fleischer à estética da dissonância defendida por Kandinsky: viver na contradição após o equilíbrio perdido, a fértil desorientação num mundo desacreditado.

A ruptura da normalidade, daquilo que a sociedade burguesa considerava normal, adequado ou conveniente, constitui o cerne das obras narrativas expressionistas mais significativas (...) Nesse contexto, os estados de 
alienamento ou de êxtase, de sonho ou de loucura, visões e utopias, o grotesco revelador do desconcerto do mundo tornam-se objeto de grande interesse narrativo. (FLEISCHER, 2002, p. 146)

Esta negação apresentada por Fleischer, que se assemelha ao "abraço ao diabólico" que mencionamos de início, culmina no grito que se projeta a ponto de extirpar o eu, que busca mover-se para surperar sua fragilidade. Diga-se de passagem, este aspecto - a violência agarrada à loucura e à alienção - é a preocupação do jovem Theodor Adorno que, em 1920, discorre de maneira atroz e fatídica sua crítica à violência expressionista. Intrigado com a exarcebação que o expressionismo apresenta à época, o autor põe em questão o pontencial de verdade que esta obra possui em meio ao movimento capaz de vencer a própria realidade. A contradição entre dois pólos - a arte e a vida - é "resolvida" pelo primeiro (a arte) que atribui a si mesmo o papel da efetividade ao se refletir na vida. Qualquer vivência é ameaçada ou, mais radicalmente, denominada pelo "eu" que acredita ter vencido a máxima plenitude - a kathársis (ADORNO, 2004, p. 610). Não se trata meramente de "eu" que se expande: o oposto do eu é sua tentativa de objetivar a subjetividade e de definirse a partir do negativo que ele mesmo produziu. Em outras palavras, o próprio movimento "eu" é que define sua identidade.

Nesta luta, para que possa ser qualquer outro, o eu não possui identidade inicial - basta pensarmos, como sugere Adorno, na peça "Mendingo" de Reinhard Sorge —, de modo que sua constituição é pelo choque com o mundo, seu vir a ser é o próprio devir. Este eu, que põe a si mesmo em risco, faz do mundo sua falsa projeção, pretensamente iguala-se a este, em última instância, se utiliza da variedade do mundo para criar o drama de si mesmo. Por esta compreensão, o expressionismo suscita um acirrado 
debate acerca das possibilidades que ainda restam à obra de arte: sua descrença no mundo e fé na subjetividade expõe, por meio do $e u$, a história em crise e aponta constantemente para uma dissolução do todo.

O conturbado encerramento da vida desencantada hora dramático e angustiante, hora místico e devoto - foi utilizado na linguagem plástica sobretudo durante os anos de guerra: vemos entre os artistas temas recorrentes como os suicídios, a loucura dos soldados sobreviventes, a malencolia da vida noturna nas cidades, o dia-a-dia sofrido dos operários nas fábricas. Mas, antes que o caos se instaurasse de fato, mostrando assim uma história que não suportou a si mesma, muitos artistas procuraramu "pressentir" este desfecho em sua poética. E é quando percebemos, de modo marcante, a passagem à violência. Finalmente, diante destas considerações, seria romantismo justamente isso? o encontro premeditado com o todo, nem que seja necessário para tanto testar a forma até as últimas consequências? Talvez não em sentido direto.

Uma das peças do complexo ideário expressionista é a contraditória negação ao regionalismo, ao sentimento de nacionalidade. Podemos detectar em Marc e Kandisnky que isto se revela na recusa em permanecer na materialidade do registro: apira-se a uma transcendência imanente, um princípio que a figura de um cavaleiro azul traz em sua placidez, o bem espiritual comum. Neste sentido, vale a frase de Däubler: "Tudo que vem a ser, pode ser iniciado somente na Terra.", nesta Terra. Ora, tal percepção, da retomada de um passado não como mera herança nacional, mas forma de resistência perante o institucionalismo, fora defendida pelo filósofo Ernst Bloch em suas considerações a posteriori em favor do expressionismo. Como precisa Carlos Eduardo Machado, Bloch afirma em Herança deste tempo que a pesquisa expressionista não pretenderia, por exemplo, 
a constituição de um lógos entre as enigmáticas montanhas da Suábia. Os artistas, ao se mostrarem relutantes aos arcaicismos (que, mais tarde, serão utilizado pelo regime nazista) prentedem instaurar uma atualidade. "Os pintores dos primeiros documentos expressionsitas, o Cavaleiro Azul, moravam na Alta-Baviera, e as pinturas de vidro de Murnau não era para eles folclore, mas testemunhas de uma fantasia própria extremamente atual." (BLOCH apud MACHADO, 1998, p. 55). Deste modo, esta relação com o passado, ao invés de uma retomada mítica - se bem que não podemos afirmá-la intencionalmente romântica -, é uma exploração da linguagem que, reavaliada, choca-se com o presente:

As pinturas sobre vidro de Murnau, pars por toto, tornaramse monumentos de uma arte popular (Heimatkunst) reacionária em que suspiram o romantismo da terra que certamente não é o que Marc e Kandinsky tinham em mente no Cavaleiro Azul. As antiguidades do país não são consideradas um pequeno Taiti local, não mais adimiradas, por assim dizer, como o país encantadao da confraternização entre os humanos no estilo de Gauguin. (Idem, Ibdem)

Os artistas, ao relizarem uma pesquisa que procura, por meio da exploração da linguagem, contradizer o presente, nada mais fazem que revelar à própria história sua não linearidade, por meio da qual passado e presente instauram trânsitos, e cada qual instaura sua respectiva teleologia. Assim, o expressionismo segue a saída romântica contra o mito cristalizado: reinventar a vida cindida e chocar contra o presente a origem (seja o indivíduo grego ou a natureza primeira). Neste sentido, é digno de nota que Romantismo, como nos informa Argan, já no século XVIII, é a arte de jardinagem equivalente ao pitoresco, "uma arte que não 
imita nem representa, mas, em consonância com as teses iluministas, opera diretamente sobre a natureza, modificando-a, corrigindo-a, adptando-a aos sentimentos e às oportunidades da vida social, isto é, colocando-a como ambiente da vida." (ARGAN, 1993, p. 12).

\section{3.}

Os anos de guerra conduzem os animais de Franz Marc à apoteose. $\mathrm{O}$ que detectamos em suas últimos anos de vida, antes de sua morte nas tricheiras, é uma controversa aposta na origem não mais como origem, mas como a marcada utopia expressionista. Em 1915, numa carta enviada do fronte à sua companheira Maria, o pintor está entregue à fé no conflito: naquele momento, trata-se para o artista da dissolução do "eterno engano" da "propriadade europeia"; pelo conflito armado, a Europa lava sua própria alma. (BEHR, p. 59) Este posicionamento, que podemos associar às leituras livres (e muitas vezes equivocadas) de Nieztsche, acometeu diversos intelectuais da corrente artística expressionsita, o que fará muitos artistas se associarem ao nacional socialismo anos mais tarde. No caso de Marc, podemos detectar em seu amadeurecimento (que nada mais é que sua fase final) alguma perigosa associação com a modernidade, dando a ver, contraditoriamente, a adesão paralela à crítica. Esta não seria, pois, uma consequência de seu encontro e sua apropriação da técnica de Delaunay em 1912? Há que se considerar ainda seu reconhecimento da importância dos futuristas italianos na publicação da revista Der Sturm, ao afirmar que estes viriam a ser pedras de toque da história da pintura moderna. A natureza, que outra era defendida em sua pureza, tornase cada vez mais veloz, tecnológica e, certamente, fatídica. Lancemos olhar sobre três obras desta fase. 
Animais em uma paisagem (Figura 3), de 1914, apresenta um espaço radicalmente transfigurado. Da direita à esquerda, o azul emana e se dispersa. Notam-se três ruminantes: um destes parece se alimentar, e sua postura é tão fleumática que se confunde com a própria paisagem; outro animal, amarelo, repousa no canto superior esquerdo distanciando-se da centralidade da tela, que é ocupada por um touro cuja feição vermelha é tornada mais agressiva com as linhas de sua face e seus chifres pretos. $\mathrm{O}$ vermelho simplesmente explode em clara oposição ao azul e chega a suprimir o amarelo que se acomoda ao fundo. À margem direita, vemos outra figura animal: uma serpente de aparência quase vegetal enrola-se disfarçadamente em um galho; suas cores se relacionam com os chifres e a face do touro.

Em 1913, a conhecida tela Destino dos animais (Figura 5) parece recorrer à salvação em meio ao caos. Os animais se orientam em direção a um ponto fictício no centro do quadro: à esquerda, raposas alinhadas; à direita, dois cavalos verdes encaram-se e são "puxados" para este epicentro e, mais abaixo, dois javalis são acompanhados por uma serpente, que se reduz a curvas entre o amarelo e o verde. $\mathrm{O}$ embate é travado aqui de modo aberto entre as cores. $\mathrm{O}$ vermelho atravessa este espaço de modo tão violento que parece "rasgar" a própria pintura. $\mathrm{O}$ azul assumese como princípio: é o fundo que se reflete e se "personifica" em um cervo de cabeça erguida. Este cervo, consciente do desfecho que ali acontece, acompanha toda a agressividade das formas agudas com seu movimento: seu pescoço esticado, em consonância com este fluxo, sugere uma altura exorbitante em nível espiritual. Atrás do quadro, escrevera Franz Marc um ditado hindu: "E toda a existência é um ardente tormento".

Também em 1914, Marc conclui a paisagem Tirol (Figura 4), contraditória em relação ao próprio título, que sugere tranquilidade e isolamento. Os habitantes são radicalmente 
desfigurados. Embora constem registros recorrentes - o lilás que acompanha o amarelo, a expansão do azul pelo espaço, o vermelho pulsante - a importância está nos traços. No centro do quadro, uma formação triangular sugere uma divindade feminina cultuada por um animal híbrido de cabeça erguida e chifres. À esquerda, massas tonais brancas pretendem equilibrar o peso que de toda a tela recebe; um galho de árvore sem folhas impõe-se austeramente em primeiro plano; num sutil horizonte, segue-se uma paisagem inóspita.

Animais em uma paisagem, a cobra assiste sorrateiramente à agressividade que eclode e contamina aos poucos toda a cena, Destino dos Animais ${ }^{10}$ e Tirol parecem apontar saídas diferentes ao mundo que não comporta sua própria força. $\mathrm{O}$ cervo, sendo o próprio destino, salta profeticamente rumo à imaterialidade prometida após o caos, ao passo que, na paisagem transfigurada de Tirol, a espiritualidade surge de modo apoteótico; ao contrário de Destino, essa apoteose não pretende unir todo "o fluir", sendo por fim totalizante, mas aponta que, no recôndito da natureza, longe do fervor, o fim já é pressentido, por assim dizer.

Ainda que o movimento expressionista tenha sua própria historicidade, não se pode negar que o eixo "subjetividade-eu" aponta para uma persistência da solução romântica às feridas da história por meio da obra de arte. Esta procedimento, que não podemos de modo algum reduzir unicamente a uma continuidade, gera, ao seu modo, uma oposição a partir da qual a obra parece se nutrir: opor-se à realidade para vencê-la e sobre ela se projetar. Embora o expressionismo traga a restrição desde a apresentação de sua força (tornando expressa a modernidade enquanto falha), sua atitude é tão romântica na medida em que 
deposita no $e u$ a mão da criação e na medida em que pretende que a própria obra, em última instância, seja a união entre a arte e a vida. Embora a obra de Franz Marc possua, por sua vez, relações outras das quais não tratamos, esta pode ser um exemplo desta relação: suas figuras animais concebem o mundo que habitam, podem construí-lo, sacralizá-lo, destruí-lo. Não se trata, como conduz a crítica comum, de uma aposta na "pureza" não-humana, mas da reinvenção que se move através e contra o racional. Sem mais nos alogarmos, caberia como resposta talvez o último dos cem aforismos que Marc escrevera no campo de batalha, donde não retornou: "Vivemos em um tempo árduo. Nossos pensamentos são árduos. Tudo deve ficar mais árduo ainda."

ILUSTRAÇÕES:

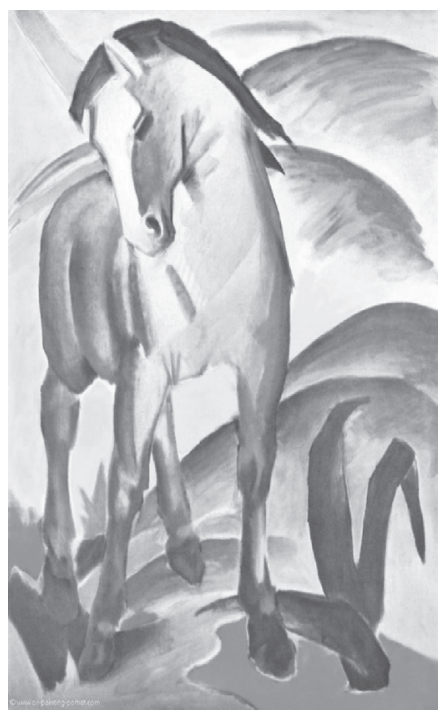

Figura 1: Franz Marc, Cavalo Azul, óleo sobre tela.

Städtische Galerie im Lenbachaus. 


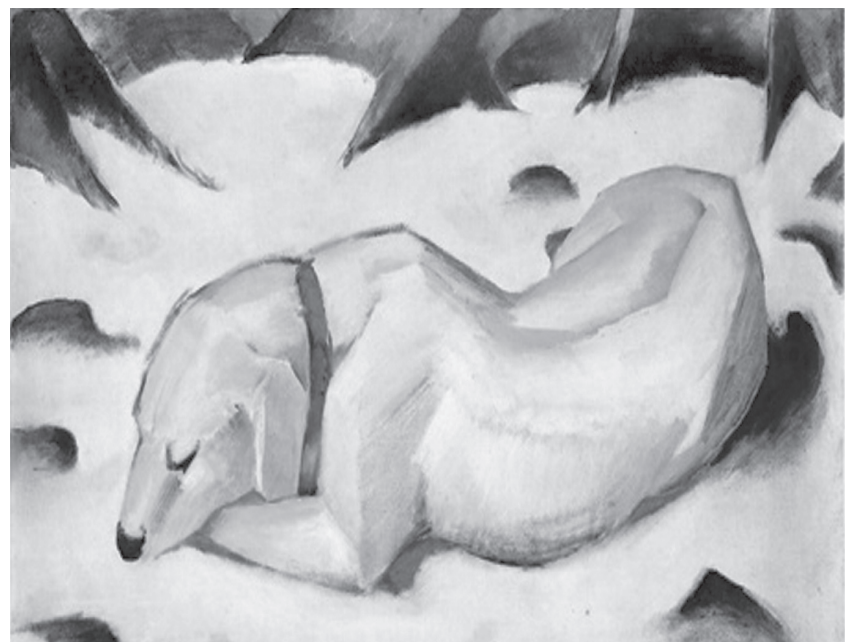

Figura 2: Franz Marc, Cão deitado na neve, óleo sobre tela. Städelsche Galerie, Frankfurt.

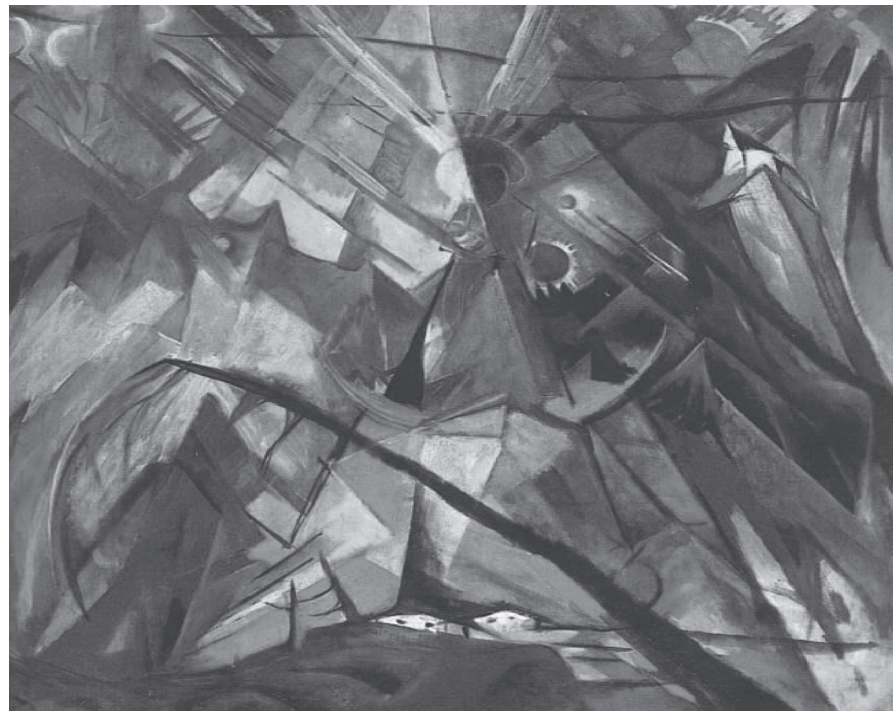

Figura 3: Franz Marc, Animais na paisagem, óleo sobre tela. Institute of Arts, Detroit. 


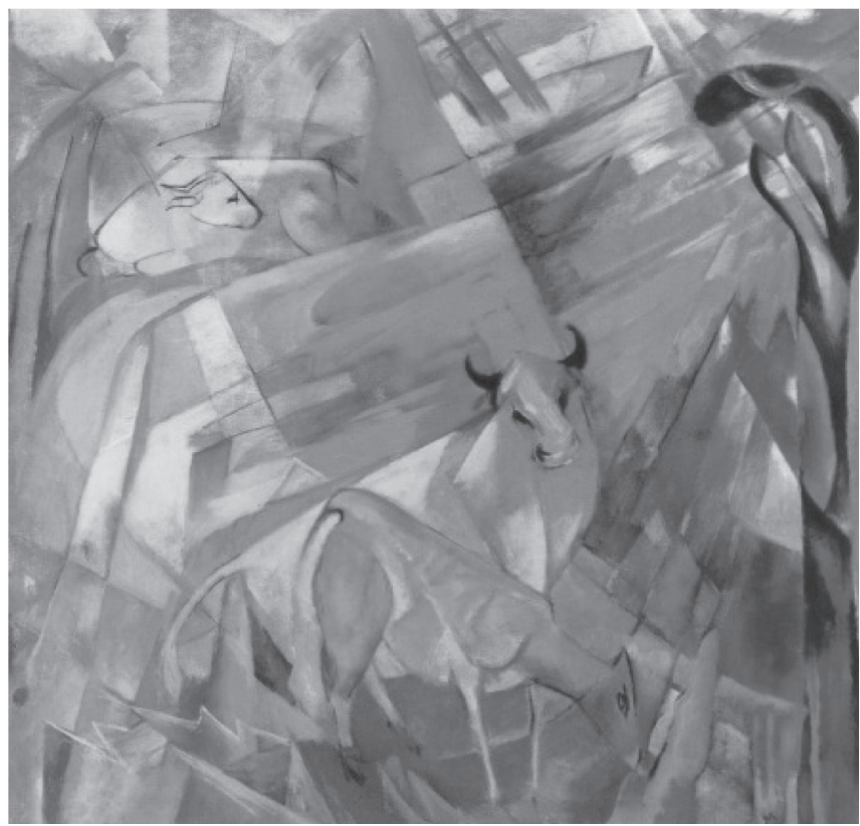

Figura 4: Franz Marc, Tirol, óleo sobre tela. Staatsgalerie Moderner Kunst, Munique.

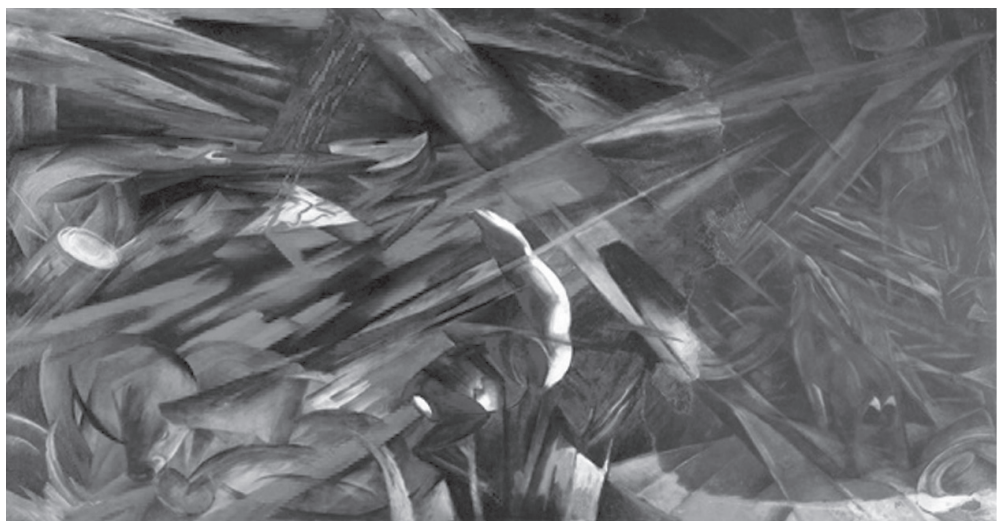

Figura 5: Franz Marc, Destino dos animais, óleo sobre tela. Kunstmuseum Basel. 


\section{NOTAS}

${ }^{1}$ Licenciado em filosofia pela Universidade de Brasília.

${ }^{2}$ Cf. República. 13a edição. Tradução Maria Helena da Rocha Pereira. Lisboa: Calouste Gulbekian, 2010. 602d. Este trecho que citamos é início da argumentação de Sócrates contra a figura do poeta.

${ }^{3}$ Leve-se em consideração que, para Hegel, a alcunha arte romântica não se aplica a histórica poética do século XIX; trata-se, porém, do desenvolvimento da arte enquanto esfera do Espírito desde a fragmentação da substância ética grega e a ascenção da era cristã até a cultura moderna da reflexão. $\mathrm{O}$ que aponta-se comumente como "Romantismo" localiza-se no momento em que a própria arte ultrapassa a si mesma, tendo há muito deixado o nível da certeza sensível para lançar-se radicalmente no terreno da reflexão, chegando a arte a se tornar notadamente conceito, a saber, por meio da poesia romântica.

${ }^{4}$ SUZUKI, Márcio. Camões em alemão. Disponível em: http://www1.folha.uol. com.br/fsp/mais/fs2105200012.htm. Acessado em 19 de fevereiro de 2014. ${ }^{5}$ Acerca da noção hegeliana de sublime, $c f$. WERLE, Marco Aurélio. A questão do fim da arte em Hegel. São Paulo: Hedra, 2011. p.102

${ }^{6}$ Devemos o termo a Roger Cardinal.

${ }^{7}$ Cabe ressaltar que o primeiro Almanaque foi publicado em 1912. Neste texto, utilizamos a segunda edição, de 1914.

${ }^{8}$ No original: "Alles was wird, kann auf Erden nur angefangen werden".

${ }^{9}$ Reinhard Piper (1879-1953), fundador da Piper Verlag, editora de Munique que publicou as primeiras edições do Almanaque Cavaleiro Azul. O autor publica neste mesmo das correspondências com Marc a obra Sobre os animais na arte.

${ }^{10}$ É digno de nota que o Destino dos Animais teve como inspiração o massacre de animais descrito na versão flaubertiana da lenda de São Julião Hospitalheiro. 


\section{REFERÊNCIAS}

ADORNO, T. W. Expressionismus und künstliche Wahrhaftigkeit. In: Gesammelten Schriften. Frankfurt: Suhrkamp, 2004.

ANDRADE, P. D. Estio no tempo: o amor entre arte e filosofia na origem do romantismo alemão. 277 pp [Tese de doutorado em filosofia]. Pontifícia Universidade Católica do Rio de Janeiro. 2009.

ARGAN, G. C. Arte moderna. Do Iluminismo aos movimentos contemporâneos. 2a edição. Tradução Denise Bottmann e Frederico Carotti. São Paulo: Companhia das Letras, 1993.

BEHR, S. Expressionismo. Tradução Rodrigo Lacerda. São Paulo: CosacNaify, 2000.

CARDINAL, R. O Expressionismo. Tradução Cristina Barczinski. Rio de Janeiro: Zahar, 1988.

FLEISCHER, M. "A realidade precisa ser criada por nós": rumos da prosa expressionista alemã. In: GUINSBURG, J. O Expressionismo. São Paulo: Perspectiva, 2002.

FLEISCHER, M. Fausto. Tradução Jenny Klabin Segall. São Paulo: 34, 2004.

HEGEL, G.W.F. Cursos de Estética. Volume III. Tradução, apresentação e notas de Marco Aurélio Werle e Oliver Tolle. São Paulo: Edusp, 2000.

KANDINSKY, W. MARC, F. Der Blaue Reiter Almanach. München: Piper, 1914. 
MACHADO, C. E. J. Um capitulo da história da modernidade estética: debate sobre o expressionismo. São Paulo: Unesp, 1998.

MARC, F. Schriften. Köln: DuMont, 1979.

PANOFSKY, E. Sobre o problema da descrição e da interpretação. In LICHTENSTEIN, J. A pintura. Volume 8. Tradução Magnólia Costa. São Paulo: 34, 2005.

PAZ, O. Os filhos do barro: do romantismo à vanguarda. Tradução Olga Savery. Rio de Janeiro: Nova Fronteira, 1982.

SZONDI, P. Poésie et poétique de l'idéalisme allemand. Tradução Jean Bollack et allii. Paris: Minuit, 1974. 